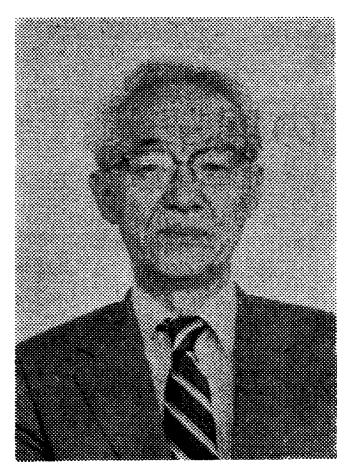

一随 カナダの大学を

半年位前に随想を書くよう要請された。その時何と なく，「カナダから帰って」といらことで扔断わりし た。今度は断わる理由がなくなったので，まとまらぬ ままに随想をしたためる。

カナダ政府の招待で, 6 大学の学長一行が 8 大学を 訪問した。私にとってカナダとは, 約30数年前にカナ ダ側から見たナイヤガラ瀑布。万国博のカナダ館, ケ ベック館。トルドー首相の日本訪問。これだけしかな かった。

1）日本教育について

ところがカナダでは日本の研究が盛んである。Area study (地域研究) の中で Asian study (アジア研究) と称して, 盛んに日本研究をやっている。バンクーバ 一にある British Columbia 大学には, Nitobe ガー デンと称する純然たる日本庭園があった。（新渡戸稲 三終生の地)。数へクタールの庭は, 日本人庭師の手 入れが良く行き届いて扣り, 八重桜散る池のほとりを ケニー学長に案内された。

この他, Queen, McGill 両大学にもアジア研究が あり, 非常に日本研究が盛んであった。さらに, 日本研 究の感じられるるらひとつの言葉は, Industry East といら言葉。これはアメリカでは言わないらしいが, カナダでは Industry West に対して用いていた。

2) 大学の財政について

各大学のスケールで多少異なるが, 教官一人当り, 12 万 17万 $\$$, あるいはFTE一人当り, $9,000 \sim 15,000$ \$となっている。財布を握っているのは州政府であ る。何といっても補助金が大学経費の60～80\%に相当 するからその影響力は大きい。

1960協定と称するものがある。カナダ政府とケベッ ク州政府で, 高等教育の補助金をどちらが真担するか を取り決めたもので，上納金を $1 \%$ 低隇して，これを 高等教育に充当することとした。これによって, 州政 府は資金の配布について大きな力を持っている。（カ ナダ国には文部省はなく，各州政府にある）

1. 学術政策と規準の規格化と実施

\section{訪 問して}

広島大学長

本会評議員 頼 実 正 弘

2. 入学および卒業の規準の設定

3. 教官の選択と任命

この 3 点以外は, 大学協議会 (州政府) を通して支 配されているとみられるように思う。

学生の払う授業料は10〜15\%となっているが，この 比率は大体日本の国立大学と同じくらいの值になって いる。

るらひとつの特徴は, 非営利事業のみならず, 営利 事業からも研究経費の導入を行っていることである。 大学によってまちまちであるが，2～8\%の割合をむ つ。これには補助金と契約の二種類がある。

補助金は, 研究者が学術的科学的優先権をとるため のプロジェクトに支払われるもので, 間接費や人件費 は含まない。結果は公表する。

契約は，後援者に優先権がある。必ずしも顕著に科 学的，学術的な調查に寄与するとは限らない。また間 接費や人件費，つまり給料の一部を支払うことができ る。しかし後援者本位であるから，結果の公表につい ては, 研究者の希望通りにはゆかないこともある。ま た, CDT (Center of Development Technique) があって, 契約に対し審查と助言が行われる由, Montreal 大学での話。

3）パートタイムの学生

ぞの大学でもパートタイムの学生がおり, その数は 正規学生の 2 割から10割までいる。イギリスの「成人 教育審議会」が, 大学は正規の学生の教育に努力を傾 注し, 成人のためのパートタイムの学習機会を開発す る必要性に目をつぶっていると言っている。つまりパ 一トタイムは，どちらかというと成人教育(生涯教育) の問題である。カナダの大学では, FTE (Full Time Equivalent) といら言葉があって, 補助金を算出 する時, パートタイム学生を正規学生に換算して考兄 る方法がとられ, 1/5 1/3という数字が使用されている。

日本では, 夜学 (二部) の制度はあるが, パートタ イムについては, これから大いに研究し, 開発してゆ かなければならない分野のひとつであらう。 